\title{
Credibility Evaluation of Online Distance Education Websites
}

\author{
Khalid Al-Omar \\ Department of Information Systems \\ King Abdulaziz University \\ Jeddah, Kingdom of Saudi Arabia
}

\begin{abstract}
Web credibility is becoming a significant factor in increasing user satisfaction, trust, and loyalty. Web credibility is particularly important for people who cannot visit an institution for one reason or other and mostly depend on the website, such as online distance education students. Accordingly, universities and educational websites need to determine the types of credibility problems they have on their websites. However, far too little attention has been paid to providing detailed information regarding the types of specific credibility problems that could be found on university websites in general, and specifically, in the Kingdom of Saudi Arabia (KSA). The aim of this paper is to study and analyze the credibility of university websites that offer distance education courses in the KSA. A total of 12 universities in Saudi Arabia were considered, which include 11 affiliated and one private university. The analysis of the data represents the level of credibility of distance education websites. Results reveal that in Saudi Arabia, distance education websites are reliable, but violate basic credibility guidelines.
\end{abstract}

Keywords-university websites; credibility; trustworthiness; online trust; website design; Saudi Arabia; distance education

\section{INTRODUCTION}

The World Wide Web (WWW) helps academic institutions distribute their messages and increase their services across the globe. Unfortunately, until now, the available technologies do not guarantee whether the web content on the Internet is reliable, up to date, and standardized, since web publishing does not involve the different stages of reviewing and filtering, as print sources do [1]. Consequently, trusting the information on websites is vital, especially for people who cannot visit an institution and depend mainly on the website-for example, online distance education students. To ensure that students join their online distance education programs and not go elsewhere, universities should be certain that their websites are aesthetic, usable, and credible. Therefore, deanships of e-learning and distance education websites at universities require reliable web-based information.

\section{WHAT IS WEB CREDIBILITY?}

Credibility is one of the most important characteristics of any user interface. Credibility is defined as believability [2, 3 ] or trustworthiness of information found on the web, which means the level to which users trust the content in a website [1]. In other words, it explains why people believe the information provided by some websites but not others. Credibility offers the ability to change user attitudes and behaviors. It can make users comfortable interacting with the website, registering their personal information, and then returning again [2].

The vast majority of researchers identify two key components of credibility: "trustworthiness" and "expertise" [4]. Trustworthiness is defined by the terms truthful and unbiased, whereas "expertise" is defined by terms such as knowledgeable and competent. The trustworthiness dimension of credibility captures the perceived goodness or morality of the source, while the expertise dimension of credibility captures the perceived knowledge and skill of the source. Highly credible websites will be perceived to have high levels of both trustworthiness and expertise.

The remainder of the paper is organized as follows: First, there is an overview of web credibility, presented in Section 2; then, a brief description of distance education in the KSA is given in Section 3. In Section 4, e-learning website selection is discussed, and then in Section 5, there is a brief description of relevant previous studies and a literature review. In Section 6, objectives of this work are presented, and in Section 7, there is a hypothesis. Section 8 presents the methodology used, Section 9 presents and discusses the results of this research, and website evaluation using automated tools is presented in Section 10. In Section 11, tool-based results are provided; in Section 12, there is a discussion of these results; and in Section 13, suggestions are offered. Finally, conclusions and future work are discussed in Section 14.

\section{A BRIEF Note ABOUT DisTANCE EDUCATION IN THE KSA}

In the present day, the Kingdom of Saudi Arabia (KSA) has witnessed growth in the number of universities in the country. Consequently, universities are facing huge competition as far as bringing in more students, with the competition being even higher for distance education programs, since the structure of online learning gives students full control over the time and place for their study. Therefore, more than ever before, the credibility of websites in higher education is becoming an increasingly important area to consider. The aim of this paper is to study and analyze several aspects related to the credibility of distance learning websites in the Kingdom of Saudi Arabia. According to the Ministry of Higher Education in the KSA, there are 35 universities in Saudi Arabia. There are 25 government universities, 10 private universities, and one university focusing exclusively on graduate education and research-King Abdullah University of Science and 
Technology (KAUST). A total of 293,665 (140,415 male and 153,250 female) students were enrolled in higher education for the 35 universities in 2014. In addition, 740 students were enrolled in KAUST (488 male and 252 female).

TABLE I. NUMBER OF ESTABLISHED UNIVERSITIES IN THE KSA

\begin{tabular}{|l|l|l|l|}
\hline $\begin{array}{l}\text { Year of } \\
\text { Establishment }\end{array}$ & $\begin{array}{l}\text { No. of } \\
\text { Government } \\
\text { Universities }\end{array}$ & $\begin{array}{l}\text { No. of } \\
\text { Private } \\
\text { Universities }\end{array}$ & Percentage \\
\hline Before 1960 & 1 & 0 & 1 \\
\hline $\begin{array}{l}\text { Between 1960 } \\
\text { and 1970 }\end{array}$ & 4 & 0 & 4 \\
\hline $\begin{array}{l}\text { Between 1970 } \\
\text { and 1980 }\end{array}$ & 3 & 1 & 4 \\
\hline $\begin{array}{l}\text { Between 1980 } \\
\text { and 1990 }\end{array}$ & 0 & 0 & 0 \\
\hline $\begin{array}{l}\text { Between 1990 } \\
\text { and 2000 }\end{array}$ & 1 & 1 & 2 \\
\hline $\begin{array}{l}\text { Between 2000 } \\
\text { and 2010 }\end{array}$ & 16 & 6 & 22 \\
\hline After 2010 & 1 & 2 & 3 \\
\hline Total & 26 & 10 & 36 \\
\hline
\end{tabular}

\section{E-LEARNING WEBSITE SELECTION}

Among the 36 universities, only 11 government universities have been authorized by the Ministry of Higher Education to offer distance education courses ranging from bachelor's to master's degree. On the other hand, only one private university (the Arab Open University) has been accredited by the Ministry of Higher Education (see Table 2). However, the number of e-learning students enrolled is not an indication of credibility, since the location of the university affects the number of enrollees.

TABLE II. NUMBER OF ONLINE DisTANCE EdUCATION STUDENTS IN THE KSA 2014

\begin{tabular}{|l|l|l|l|l|}
\hline No & University & Male & Female & Total \\
\hline 1 & $\begin{array}{l}\text { King Abdulaziz } \\
\text { University (KAU) }\end{array}$ & 1,959 & 1,909 & 3,868 \\
\hline 2 & $\begin{array}{l}\text { Islamic University in } \\
\text { Madinah }\end{array}$ & 700 & 0 & 700 \\
\hline 3 & IMAUM & 5,156 & 3,733 & 8,889 \\
\hline 4 & $\begin{array}{l}\text { King Faisal University } \\
\text { (KFU) }\end{array}$ & 5,911 & 6,901 & 1,2812 \\
\hline 5 & TAIBUAHU & 1,530 & 1,713 & 3,243 \\
\hline 6 & Taif University (TU) & 2,014 & 1,041 & 3,055 \\
\hline 7 & $\begin{array}{l}\text { Jazan University } \\
\text { (JAZANU) }\end{array}$ & 876 & 810 & 1,686 \\
\hline 8 & Aljouf University (JU) & 199 & 66 & 265 \\
\hline 9 & Najran University (NU) & 1,005 & 977 & 1,982 \\
\hline 10 & $\begin{array}{l}\text { University of Dammam } \\
\text { (UD) }\end{array}$ & 957 & 1,241 & 2,198 \\
\hline 11 & $\begin{array}{l}\text { Saudi Electronic } \\
\text { University (SEU) }\end{array}$ & 4,490 & 2,771 & 7,261 \\
\hline 12 & Arab Open University & 1,914 & 2,340 & 4,254 \\
\hline
\end{tabular}

Currently, there is a huge demand for online distance learning in the KSA. Mainly, there are two main factors that influence online learning. First, the KSA is a large country with very few universities open compared to its size. Second, the KSA government encourages its employees to get an advanced degree to become eligible for promotion to a higher position. However, the main reason that causes more demand for distance education programs is the acceptance of online distance learning by the Ministry of Civil Service. Therefore, the demand for a place to study online learning at the university is still much more than is available. Thus, every academic year, thousands of students are left out of universities [5]. As a result, many universities have recently been offering distance education learning programs. As such, sooner or later, deanships of distance learning programs will face increasing pressure to enhance the credibility of their websites.

\section{LITERATURE REVIEW}

In recent years, factors affecting the credibility of websites have been the subject of many research projects, such as social networking sites [6], mobile website interfaces [7], e-learning, e-government [8, 9], and e-commerce (e.g. [2, 6, 10-12]). BJ Fogg's team at the Stanford Web Credibility Project conducted a remarkable study to investigate which design elements positively or negatively influence credibility. Fogg et al. conducted a large-scale online survey of more than 1,400 participants, both from the U.S. and Europe, evaluating 51 different website elements. In this study, they identified five elements that have a positive effect on the credibility of a website: real-world feel, ease of use and usefulness, expertise, trustworthiness, and tailoring [2]. Two of these credibility elements, ease of use and tailoring, closely relate to usability [13]. Also, the researchers found that the two factors hurting credibility were "commercial implications" and "amateurism." Based on these findings, Fogg et al. [2] proposed seven guidelines to create highly credible websites, which they expanded on further by setting up the Stanford Guidelines for Web Credibility [14].

Furthermore, Fogg et al. conducted a study with more than 2,500 participants to shed light on what leads people to believe, or not believe, what they find online [15]. Participants evaluated the credibility of two live websites on a similar topic (health). They concluded that the design of the site was mentioned most frequently, followed by comments about information structure and information focus. Also, in this study authors shared participants' feedback in the top 18 areas that people noticed when evaluating website credibility.

\section{OBJECTIVES}

The main objective of this study is to examine the web credibility of e-learning and distance education deanships websites at universities in the KSA, compare the online distance education websites of universities in the KSA, and then offer suggestions for the design of an ideal online distance education website for a university to increase the site's credibility.

\section{HYPOTHESES}

Hypotheses applied for the study were:

- A majority of the universities in Saudi Arabia have hosted websites on the Internet.

- The university websites are heterogeneous in their structure and content.

- Most of the websites do not follow established guidelines. 
- The majority of the universities in Saudi Arabia have serious issues with web credibility.

\section{METHODOLOGY}

The first part of our evaluation methodology was intended to evaluate the credibility of the e-learning websites of Saudi universities by using the self-evaluation method. The data for this study was collected through this method [15], which included the following:

- Designing a checklist from previous research [1, 2].

- Evaluation of the websites. ${ }^{1}$

- Data collection.

- Analysis and interpretation of data.

The credibility evaluation methods conducted by human involvement can assess only the external attributes of the website rather than its internal attributes. External attributes depend on the website and its usage, while the internal attributes of the website depend on how the website has been designed and developed [16]. The internal attributes of the website can be assessed and evaluated using automated tools. Both internal and external attributes are required. In this study, the total size of the website, total size of images, percentage of images in the total size, and the download times were collected. Slow websites gave an indication that the website was uncertain. However, the external attributes of the website were assessed and evaluated by self-evaluation.

\section{DATA ANALYSIS AND DISCUSSION}

Among the 36 universities, only 12 have been authorized by the Ministry of Higher Education to offer distance education courses ranging from bachelors' to masters' degrees. In this study, all 12 universities were considered, evaluated, and analyzed. However, there has been a phenomenal growth of elearning and distance education in Saudi Arabia universities since 2009 (Table 3).

TABLE III. YEAR OF ESTABLISHMENT OF E-LEARNING AND DISTANCE EDUCATION DEANSHIPS AT UNIVERSITIES IN THE KSA

\begin{tabular}{|l|l|l|l|}
\hline \multirow{2}{*}{ No } & \multirow{2}{*}{ University } & \multicolumn{2}{|l|}{$\begin{array}{l}\text { Year of } \\
\text { Establishment }\end{array}$} \\
\cline { 3 - 4 } & & Gregorian & Hijri \\
\hline \multirow{2}{*}{1} & $\begin{array}{l}\text { King Abdulaziz University } \\
\text { (KAU) }\end{array}$ & 2002 & 1423 \\
\hline 2 & Islamic University in Madinah & 1961 & 1381 \\
\hline 3 & IMAUM & 2007 & 1428 \\
\hline 4 & King Faisal University (KFU) & 2009 & 1430 \\
\hline 5 & TAIBUAHU & 2005 & 1426 \\
\hline 6 & Taif University (TU) & 2011 & 1432 \\
\hline 7 & Jazan University (JAZANU) & 2009 & 1430 \\
\hline 8 & Aljouf University (JU) & 2007 & 1428 \\
\hline 9 & Najran University (NU) & 2011 & 1432 \\
\hline 10 & University of Dammam (UD) & 2010 & 1430 \\
\hline 11 & $\begin{array}{l}\text { Saudi Electronic University } \\
\text { (SEU) }\end{array}$ & 2011 & 1432 \\
\hline 12 & Arab Open University & 2002 & 1423 \\
\hline
\end{tabular}

${ }^{1}$ www.websiteoptimization.com
In 2011 Saudi Electronic University (SEU) became the first government educational institution specializing in distance education in the KSA. SEU is offering both graduate and undergraduate degree programs.

All the universities agreed that students should attend campuses for the final test. However, not all authorized universities provide complete full-distance education programs (see Table 4). There are two universities that have adopted the Blended System in e-teaching: Saudi Electronic University (SEU) and Arab Open University in the KSA. Students at SEU have to attend $25 \%$ of classes in the form of direct lectures, and another $25 \%$ as virtual classes. The rest (50\%) are distributed among educational forums and following up on the digital learning content. Students at the Arab Open University in the KSA have to attend $25 \%$ in the form of direct lectures, and the rest $(75 \%)$ are distributed among educational forums and following up on the digital learning content.

\section{TABLE IV. WAY To StUdy DISTANCE EdUCATION AT UNIVERSITIES IN} THE KSA

\begin{tabular}{|l|l|l|}
\hline No & University & Learning Style \\
\hline 1 & $\begin{array}{l}\text { King Abdulaziz University } \\
\text { (KAU) }\end{array}$ & Distance Education \\
\hline 2 & Islamic University in Madinah & Distance Education \\
\hline 3 & IMAUM & Distance Education \\
\hline 4 & King Faisal University (KFU) & Distance Education \\
\hline 5 & TAIBUAHU & Distance Education \\
\hline 6 & Taif University (TU) & Distance Education \\
\hline 7 & Jazan University (JAZANU) & Distance Education \\
\hline 8 & Aljouf University (JU) & Distance Education \\
\hline 9 & Najran University (NU) & Distance Education \\
\hline 10 & University of Dammam (UD) & Distance Education \\
\hline & & $\begin{array}{l}\text { Blended Learning: } \\
25 \% \text { as direct (face-to- } \\
\text { face) lectures } \\
25 \% \text { as virtual } \\
\text { (online) classes } \\
50 \% \text { participating in the } \\
\text { course }\end{array}$ \\
\hline 11 & $\begin{array}{l}\text { Saudi Electronic University } \\
\text { (SEU) }\end{array}$ & $\begin{array}{l}\text { Blended Learning: } \\
25 \% \text { as direct (face-to- } \\
\text { face) lectures }\end{array}$ \\
\hline 12 & $\begin{array}{l}\text { Arab Open University in the } \\
\text { KSA }\end{array}$ \\
\hline
\end{tabular}

Table 5 shows that all government universities have their URL with "edu.sa," and just a single private university used ".org" for their university URL.

TABLE V. ClASSIFICATION OF WEBSITES BY URL EXTENSION

\begin{tabular}{|l|l|l|}
\hline URL & .edu.sa & .org \\
\hline Number of & 11 Government & 1 Private \\
Universities & Universities & University \\
\hline
\end{tabular}

\section{Website Evaluation using Automated Tools}

Credibility assessment methods that are conducted by human involvement (users and experts) can assess only the external attributes of the website (such as the usability of the website) rather than its internal attributes (such as webpage speed analysis). Testing website download speed and the size of the webpage is definitely essential, since it influences the usability and credibility of any website. The data obtained might not be accurate, but is used only to represent the extent and the level of website download speed and size of the 
webpage possessed by the university websites in Saudi Arabia. The webpage analyzer 0.98 is a free tool from Website Optimization utilized to measure the website performance tool and webpage speed analysis to improve a website's performance. In this study, the total size of the website, total size of images, percentage of images in the total size, and the download times have been collected.

Table 6 shows that the expertise factors for websites help users gain more credibility. The majority ( 83 percent) of the elearning university websites offer information in the English language. Unfortunately, 95 percent of the English content provided is not exactly the same as the Arabic content. Using a language other than English in the e-learning university websites is rarely found. Besides, one can rarely find information about research activities or research articles on the site. On the other hand, 67 percent of the e-learning university websites appear on the first page of Search Engines such as Google, Yahoo, and Bing. While the majority of the universities have information about "research activities," some of them provide the "project titles" as well.

TABLE VI. ClassificATION OF WEBSITES By EXPERTISE FACtORS

\begin{tabular}{|l|l|}
\hline Expertise factors & $\begin{array}{l}\text { Total } \\
\text { (Percentage) } \\
\mathbf{n = 1 2}\end{array}$ \\
\hline $\begin{array}{l}\text { The site offers information in more than one } \\
\text { language (e.g. English and Arabic). }\end{array}$ & $10(83)$ \\
\hline $\begin{array}{l}\text { Information about research activities is } \\
\text { given. }\end{array}$ & $3(25)$ \\
\hline $\begin{array}{l}\text { Research articles available in the site } \\
\text { authored by students and faculty (IR). }\end{array}$ & $3(25)$ \\
\hline $\begin{array}{l}\text { The site appeared on the first page of } \\
\text { Google search engine results }\end{array}$ & $8(67)$ \\
\hline Yahoo search engine results & $8(67)$ \\
\hline Bing search engine results & $8(67)$ \\
\hline $\begin{array}{l}\text { URL matches the name or acronym of the } \\
\text { institute. }\end{array}$ & $12(100)$ \\
\hline $\begin{array}{l}\text { The site is large (e.g., not less than five } \\
\text { pages). }\end{array}$ & $12(100)$ \\
\hline
\end{tabular}

TABLE VII. Classification OF Websites by EASY-to-USE/NAVIGATION FACTOR

\begin{tabular}{|l|l|}
\hline $\begin{array}{l}\text { Website classification by easy-to- } \\
\text { use/navigation factor }\end{array}$ & $\begin{array}{l}\text { Total } \\
\text { (Percentage) } \\
\text { n=12 }\end{array}$ \\
\hline $\begin{array}{l}\text { The site lets users search for past content (i.e., } \\
\text { archives). }\end{array}$ & $9(75)$ \\
\hline The site looks professionally designed. & $10(83)$ \\
\hline $\begin{array}{l}\text { The site is arranged in a way that makes sense } \\
\text { to users. }\end{array}$ & $6(50)$ \\
\hline The site takes a long time to download. & $4(33)$ \\
\hline The site is difficult to navigate. & $5(42)$ \\
\hline Navigation path. & $9(75)$ \\
\hline Site map is given. & $1(8)$ \\
\hline Search facility available. & $8(67)$ \\
\hline Active and inactive links are clearly visible. & $0(0)$ \\
\hline $\begin{array}{l}\text { It is easy to navigate logically according to } \\
\text { the broader category. }\end{array}$ & $6(50)$ \\
\hline The site has a picture gallery. & $8(67)$ \\
\hline It has thumbnail-size or full-size pictures. & $4(33)$ \\
\hline Homepage link is available on all subpages. & $7(58)$ \\
\hline
\end{tabular}

Table 7 shows that the majority of the websites look like they have been professionally designed ( 83 percent), and allow users to search past content (75 percent). However, half of the e-learning university websites in Saudi Arabia have proper structure and logically arranged content (50 percent). Unfortunately, it comes as a surprise that even large websites fail to make active and inactive links clearly visible. The structure of the website and its navigation plays a major role in website credibility, so it is odd to note that only one university website provides navigation tools such as a site map.

The "validity" factor helps to evaluate the importance and role of a website. Table 8 shows that all the websites (100 percent) are maintained without any internal or external advertisements and can "distinguish between link and line of statement" clearly. Also, half of the universities associate with other renowned institutions or organizations. Unfortunately, more than half of the websites (58 percent) maintain a dead link. Further, the top credibility criterion, "when the site was updated," is found among the universities in Saudi Arabia on the main page, whereas it is rarely found for other pages in the website. Also, even large universities do not provide information about the students' achievements, or provide students' records.

TABLE VIII. Classification OF Websites by VAlidity Factor

\begin{tabular}{|l|l|}
\hline Validity factor & $\begin{array}{l}\text { Total } \\
\text { (Percentage) } \\
\text { n=12 }\end{array}$ \\
\hline $\begin{array}{l}\text { Association with other renowned } \\
\text { institutions/organizations is } \\
\text { mentioned. }\end{array}$ & $6(50)$ \\
\hline $\begin{array}{l}\text { Information about students' } \\
\text { achievements or records is given. }\end{array}$ & $4(33)$ \\
\hline $\begin{array}{l}\text { The site is maintained without any } \\
\text { dead links. }\end{array}$ & $7(58)$ \\
\hline $\begin{array}{l}\text { Able to distinguish between link and } \\
\text { line of statement. }\end{array}$ & $12(100)$ \\
\hline $\begin{array}{l}\text { There is information about when the } \\
\text { site was updated. }\end{array}$ & $5(42)$ \\
\hline Calendar of events is given. & $7(58)$ \\
\hline $\begin{array}{l}\text { The site is maintained without any } \\
\text { internal/external advertisement }\end{array}$ & $12(100)$ \\
\hline
\end{tabular}

TABLE IX. Classification OF Websites by Reliability Factors

\begin{tabular}{|l|l|}
\hline Reliability factors & $\begin{array}{l}\text { Total } \\
\text { (Percentage) } \\
\text { n=12 }\end{array}$ \\
\hline History of the university is mentioned. & $10(83)$ \\
\hline $\begin{array}{l}\text { Information about affiliation or } \\
\text { accreditation is mentioned. }\end{array}$ & $7(58)$ \\
\hline There is a link to send the complaint. & $12(100)$ \\
\hline There is a link to send feedback. & $12(100)$ \\
\hline $\begin{array}{l}\text { Head of Departments and other faculty } \\
\text { information is provided with their } \\
\text { qualifications. }\end{array}$ & $6(50)$ \\
\hline $\begin{array}{l}\text { The site displays photos of offices or staff } \\
\text { members }\end{array}$ & $5(42)$ \\
\hline $\begin{array}{l}\text { Information about ISO Certification is } \\
\text { provided. }\end{array}$ & $3(25)$ \\
\hline $\begin{array}{l}\text { The site has copyright registration, and the } \\
\text { information about same is given. }\end{array}$ & $12(100)$ \\
\hline Postal address is given. & $12(100)$ \\
\hline Telephone number with STD code is given. & $12(100)$ \\
\hline Contact e-mail ID is given. & $12(100)$ \\
\hline
\end{tabular}


Table 9 explains that almost all the universities provide the contact details, history, copyright information, "feedback" feature, and give users the ability to make a complaint through their website. Only 50 percent of the universities provide information about ISO Certification.

Table 10 shows that all the websites have graphics or pictures (100 percent), and in the majority (92 percent) of the websites, the background and text color match. Unfortunately, 42 percent of the websites do not have a responsive web design. The responsive design of the websites is important since many websites do not fit into a one-page display. In addition, not all websites provide information about the screen resolution and browser compatibility. Furthermore, in half of the websites, the site's page format is followed in all the subpages.

\section{TABLE X. ClasSification OF WEBSITES by DESIGN FACTOR}

\begin{tabular}{|l|l|}
\hline $\begin{array}{l}\text { Classification of websites by design } \\
\text { factor }\end{array}$ & $\begin{array}{l}\text { Total } \\
\text { (Percentage) } \\
\mathbf{n = 1 2}\end{array}$ \\
\hline There are graphics on the site. & $12(100)$ \\
\hline There is animation on the site. & $7(58)$ \\
\hline $\begin{array}{l}\text { The background and font color } \\
\text { matches. }\end{array}$ & $11(92)$ \\
\hline Number of visitors is given. & $2(17)$ \\
\hline View resolution is suggested. & $0(0)$ \\
\hline Browser compatibility is suggested. & $1(8)$ \\
\hline Responsive web design. & $5(42)$ \\
\hline $\begin{array}{l}\text { The site's page format is followed in } \\
\text { all the subpages. }\end{array}$ & $6(50)$ \\
\hline
\end{tabular}

\section{TOOL-BASED RESULTS}

In this part of the evaluation, automated assessment tools were used to assess website credibility. The results obtained from the WebPage Analyzer are presented in Table 11.

TABLE XI. Classification of Websites by WebPage Size AND DOWNLOAD SPEED

\begin{tabular}{|l|l|l|l|l|}
\hline $\begin{array}{l}\text { Name of } \\
\text { the } \\
\text { university }\end{array}$ & $\begin{array}{l}\text { Total } \\
\text { size } \\
\text { of the } \\
\text { websit } \\
\text { e }\end{array}$ & $\begin{array}{l}\text { Total } \\
\text { size } \\
\text { of the } \\
\text { images }\end{array}$ & $\begin{array}{l}\text { Percen- } \\
\text { tage } \\
\text { of } \\
\text { images } \\
\text { in } \\
\text { total } \\
\text { size }\end{array}$ & $\begin{array}{l}\text { Download } \\
\text { time at } \\
56 \mathrm{~K} \\
\text { connectio } \\
\text { ns }\end{array}$ \\
\hline KAU & $\begin{array}{l}18857 \\
81\end{array}$ & 930851 & 55 & 393.63 \\
\hline IU & $\begin{array}{l}30131 \\
13\end{array}$ & 451273 & 98 & 949.76 \\
\hline IMAUM & $\begin{array}{l}28450 \\
1\end{array}$ & 61956 & 6 & 61.10 \\
\hline KFU & $\begin{array}{l}10174 \\
85\end{array}$ & 734151 & 19 & 212.18 \\
\hline $\begin{array}{l}\text { TAIBUAH } \\
\text { U }\end{array}$ & $\begin{array}{l}97412 \\
4\end{array}$ & 789597 & 74 & 212.74 \\
\hline TU & $\begin{array}{l}21552 \\
86\end{array}$ & $\begin{array}{l}125019 \\
0\end{array}$ & 44 & 441.35 \\
\hline JAZANU & $\begin{array}{l}31268 \\
33\end{array}$ & 458363 & 99 & 969.56 \\
\hline JU & $\begin{array}{l}24613 \\
88\end{array}$ & $\begin{array}{l}227385 \\
7\end{array}$ & 72 & 514.35 \\
\hline NU & $\begin{array}{l}45799 \\
8\end{array}$ & 448225 & 11 & 93.88 \\
\hline UD & $\begin{array}{l}25289 \\
54\end{array}$ & $\begin{array}{l}203900 \\
3\end{array}$ & 84 & 525.42 \\
\hline SEU & 629 & 0 & 0 & 0.53 \\
\hline
\end{tabular}

The web optimization's WebPage Speed Report has the connection rate starting from $1.44 \mathrm{Mbps}$ to $14.4 \mathrm{~K}$. According to the usability guidelines [17], the optimal download time for a homepage is 10 seconds. So, for better download speed, it is suggested to design $45 \mathrm{~kb}$ to $55 \mathrm{~kb}$-sized homepages. Table 14 shows that only Arab Open University falls in the $<10$ seconds category, and only two universities fall under the $>100$ seconds category. Other homepages of universities in Saudi Arabia fall under the $>200$ seconds category. Saudi Arabia has pictures, which occupies nearly 70 to 98 percent of the overall website size.

\section{RESUlts AND DisCUSSION}

Table 12 presents a summary of the score for each of the 12 university websites. For the "design" factor, only the SU and KAU website scored more than half of the total, where the rest scored half or less. The SEU, NU, KAU, and IU university websites achieved the highest score (61 percent) for the "easy to use" factor, where the rest of the websites scored less than half. This indicates that half of the university websites have usability problems in their websites. On the other hand, most university websites achieved a high score on "reliability factors." The JU university website scored the lowest for both the "validity" and "expertise" factors, followed by the NU university website. Three university (KAU, KFU, and SEU) websites achieved full marks in the expertise area.

TABLE XII. CREDIBILITY SCORE

\begin{tabular}{|l|l|l|l|l|l|}
\hline University & $\begin{array}{l}\text { Design } \\
\text { factor } \\
(8)\end{array}$ & $\begin{array}{l}\text { Easy } \\
\text { to } \\
\text { use } \\
(13)\end{array}$ & $\begin{array}{l}\text { Reliability } \\
\text { factors } \\
(11)\end{array}$ & $\begin{array}{l}\text { Validity } \\
\text { factors } \\
(7)\end{array}$ & $\begin{array}{l}\text { Expertise } \\
(9)\end{array}$ \\
\hline KAU & 6 & 7 & 10 & 7 & 9 \\
\hline IU & 3 & 7 & 9 & 4 & 7 \\
\hline IMAUM & 3 & 4 & 8 & 6 & 6 \\
\hline KFU & 4 & 3 & 8 & 4 & 9 \\
\hline TAIBUAHU & 3 & 2 & 7 & 5 & 7 \\
\hline TU & 3 & 6 & 10 & 4 & 4 \\
\hline JAZANU & 3 & 4 & 7 & 4 & 3 \\
\hline JU & 3 & 2 & 6 & 1 & 0 \\
\hline NU & 3 & 8 & 8 & 3 & 3 \\
\hline UD & 4 & 5 & 7 & 2 & 6 \\
\hline SEU & 6 & 8 & 10 & 7 & 9 \\
\hline
\end{tabular}

Figure 1 shows the overall scores for each of the 12 university websites. A maximum score of 564 could be achieved, as 47 criteria for each website. The SUE website received the highest score (40), followed by KAU (39). The least credible was the JU website (12). The rest of the university websites achieved half of the score or above. 


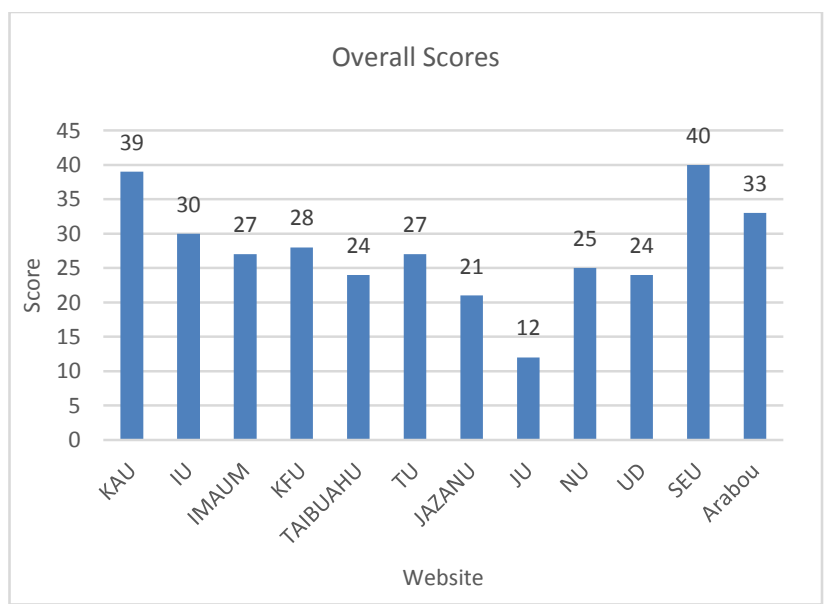

Fig. 1. Overall scores

Figure 2 reveals that, in general, the "easy to use" factor is the most violated web credibility factor among Saudi Arabia universities, followed by the "design factor." The reliability factor achieved the highest score (75\%) among Saudi Arabia universities.

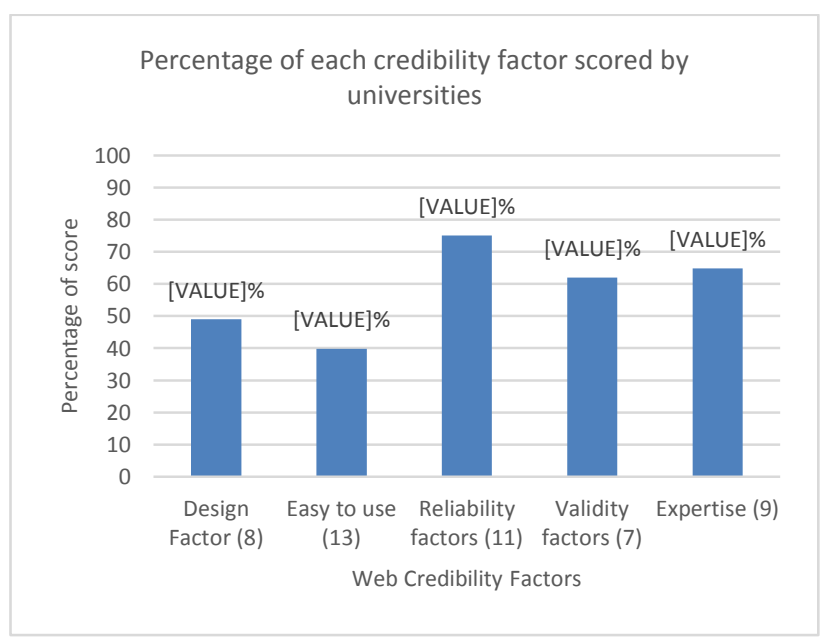

Fig. 2. Percentage of each credibility factor scored by the universities

\section{SUGGeSTIONS}

1) A majority of the university websites in Saudi Arabia do not provide any information about students' achievements or records. Hence, it is mandatory in the future to show student records.

2) A majority of the university websites in Saudi Arabia are not updated regularly and do not indicate the date of the last update. Doing so will add more credibility to the site.

3) E-learning university websites should associate their websites with other renowned institutions and organizations such as The National Center for e-Learning and Distance Learning. This association will be a value added to the website, which will increase its credibility.

4) Many websites do not fit into a one-page display, which is necessary given the large number of different devices used to access websites. Therefore, universities' website designs should have a responsive layout. This design will be a value added to the website, which will increase its credibility.

5) The structure of the website and its navigation plays a major role in website credibility. Therefore, universities should provide a site map, navigation path, and internal search engine, which will be a value added to the website, thereby increasing credibility.

6) The page format for the university websites should follow the same style in all the subpages, since this will help prevent user confusion and add credibility to the website.

7) The university websites should focus on maintaining their websites without any dead links, since such links will strongly undermine the websites' credibility.

8) Normally a website will have many links; therefore, it is critical to help users distinguish between active and inactive links. This approach will be a value added to the website, which will increase its usability as well as its credibility.

9) University websites should make navigation easier by providing a site map, and the internal search engine will be a value added to the website, which will also increase its credibility.

10)Providing more than one language can help enhance the credibility of the websites. However, users sometimes switch from one language to another, so it is critical to make the websites look the same in all languages.

\section{CONCLUSION AND FUTURE WORK}

The purpose of the current study was to examine the web credibility of distance education websites in Saudi Arabia universities. The results of this investigation show that university websites are reliable and are designed well, but violate basic usability, accessibility, and credibility guidelines. Therefore, university websites in Saudi Arabia should be required to be evaluated periodically using established criteria such as usability, accessibility, and credibility. Consequently, this will help the universities improve their websites to meet users' needs. The current study should be repeated using the user evaluation method. This approach will contribute to understanding how Saudis perceive website credibility. Another possible area of future research would be to investigate which usability and accessibility factors impact negatively on web credibility.

\section{REFERENCES}

[1] R. Babu, A. N. Kumar, and S. Gopalakrishnan, "Credibility of university websites in Tamil Nadu," DESIDOC Journal of Library \& Information Technology, vol. 29, pp. 16-28, 2009.

[2] Fogg, J. Marshall, O. Laraki, A. Osipovich, C. Varma, N. Fang, et al., "What makes Web sites credible?: a report on a large quantitative study," in Proceedings of the SIGCHI conference on Human factors in computing systems, 2001, pp. 61-68.

[3] S. Tseng and B. Fogg, "Credibility and computing technology," Communications of the ACM, vol. 42, pp. 39-44, 1999.

[4] B. Fogg, T. Kameda, J. Boyd, J. Marshall, R. Sethi, M. Sockol, et al., "Stanford-Makovsky web credibility study 2002: investigating what makes web sites credible today," Report from the Persuasive Technology Lab, available online at http://captology. stanford. edu/pdf/Stanford-MakovskyWebCredStudy2002-pre\% lim. pdf, 2002. 
[5] Al-Shehri, "E-learning in Saudi Arabia:'To E or not to E, that is the question'," Journal of family \& community medicine, vol. 17, pp. 147$150,2010$.

[6] L. Song, J. Lai, and J. Li, "Identifying Factors Affecting Individual Perceived Credibility on SNS," in Proceedings of the The 3rd Multidisciplinary International Social Networks Conference on SocialInformatics 2016, Data Science 2016, 2016, p. 2.

[7] K. Oyibo, Y. S. Ali, and J. Vassileva, "An Empirical Analysis of the Perception of Mobile Website Interfaces and the Influence of Culture," in Proceedings of the International Workshop on Personalization in Persuasive Technology (PPT'16), Salzburg, Italy, 2016.

[8] M. A. A. Rashid, M. N. A. Othman, and M. Z. Othman, "Website Quality as a Determinant of E-government User Satisfaction Level," in Regional Conference on Science, Technology and Social Sciences (RCSTSS 2014), 2016, pp. 157-168.

[9] Z. Huang and M. Benyoucef, "Usability and credibility of e-government websites," Government Information Quarterly, vol. 31, pp. 584-595, 2014.

[10] N. Wathen and J. Burkell, "Believe It or Not: Factors Influencing Credibility on the Web," JOURNAL OF THE AMERICAN SOCIETY FOR INFORMATION SCIENCE AND TECHNOLOGY, vol. 53, pp. 134-144, 2002.

[11] Alsudani and M. Casey, "The effect of aesthetics on web credibility," in Proceedings of the 23rd British HCI Group Annual Conference on
People and Computers: Celebrating People and Technology, 2009, pp. 512-519.

[12] J. F. George, G. Giordano, and P. A. Tilley, "Website credibility and deceiver credibility: Expanding Prominence-Interpretation Theory," Computers in Human Behavior, vol. 54, pp. 83-93, 2016.

[13] J. Nielsen, "Usability 101: Introduction to usability," ed, 2003.

[14] B. Fogg, "Stanford guidelines for web credibility: A research summary from the Stanford Persuasive Technology Lab," Stanford University. Retrieved August, vol. 10, p. 2011, 2002.

[15] B. Fogg, C. Soohoo, D. R. Danielson, L. Marable, J. Stanford, and E. R. Tauber, "How do users evaluate the credibility of Web sites?: a study with over 2,500 participants," in Proceedings of the 2003 conference on Designing for user experiences, 2003, pp. 1-15.

[16] Brajnik, "Automatic web usability evaluation: what needs to be done," in Proc. Human Factors and the Web, 6th Conference, 2000.

[17] J. Nielsen, "Designing web usability: the practice of simplicity New Riders Publishing," Indianapolis, Indiana, 2000.

\section{AUTHOR PROFILE}

Dr. Khalid Hamad Alomar: Assistant Professor of Information Systems, Faculty of Computing \& Information Technology, King Abdul-Aziz University, major in software engineering and Human Computer Interaction. Currently, Dr. Khalid is a vice dean of the Technical Affairs of E-learning and Distance Education at King Abdul-Aziz University. 